\title{
Africa and the francophonie of tomorrow: an attempt to measure the population of the Francophonie from now to 2060
}

\author{
Richard Marcoux \\ Professor in the Department of Sociology, Faculty of Social Sciences, \\ Director, Observatoire démographique et statistique de l'espace \\ francophone (ODSEF), Université Laval. \\ Richard.Marcoux@soc.ulaval.ca \\ Mamadou Kani Konaté \\ Sociologist, Director of \\ Centre d'appui à la recherche et à la formation (CAREF), \\ Bamako, Mali.
}

\section{Abstract}

Habib Bourgiba, Hamani Diori and Léopold Sédar Senghor are considered the fathers of the Organisation Internationale de la Francophonie (OIF), an international community created in the early 1960s that currently unites more than thirty countries where the French language is given a major role in public life, education, the arts, law, the media, etc. Some present the OIF as a neo-colonial organization, while others think of it as protecting the world's cultural diversity in the face of globalization. Regardless, this assembly of countries around the world has played and should continue to play a significant role in international politics. However, the configurational changes this Francophone community has experienced since its inception in the 1960s are nothing compared with those we predict for the next 50 years. In fact, the most recent demographic trends outlined in the United Nations' latest population projections are leading to a major reconfiguration of the demographic weight of the countries of the world, particularly in Africa. In this context, we were interested to try a forward-looking exercise based on these most recent projections from the UN that could allow us to define the Francophonie of tomorrow by exploring the evolution of Africa's demographic weight. In the coming decades, what will be the size and the geographic distribution of the Francophone population? How has Africa's demographic weight in the espace francophone evolved? And how will it evolve in the future? In this article, we try to better define the demographic outline of tomorrow's Francophonie by drawing on different definitions of the espace francophone, while highlighting some of the political and social issues of this forward-looking exercise for the Francophone community in general, and for Africa in particular.

\section{Introduction}

How big is the population of the Francophonie? What is the distribution of this population throughout the world today?
And what will be its geographic distribution in the coming decades? Will it have the same geographic configuration or will it be concentrated in several regions? In a context where globaliza- 
tion seems to rhyme with Anglicization-with English becoming firmly established as the language of communication in the increasingly frequent exchanges between distinct linguistic groups, particularly through Information Technologies-, we were interested to try a forward-looking exercise that could allow us to define the Francophonie of tomorrow, but only in respect of its demographic weight and distribution trends on the different continents.

Of course, the Francophonie's role in the world cannot be summed up by a mere census of the number of individuals in Francophone countries. In fact, it is through the initiative of these countries' institutions, politicians, artists, scientists and economists that the Francophone world can be heard. It is nonetheless important to recognize that a group's demographic weight is no marginal attribute because, as we already know, it represents the central element in the decision-making process of all democracies. A group's demographic weight is actually a major social and political stake in many debates, whether on local, national or international levels. In what is generally called the world community, Francophone countries can make themselves heard if and when they are significant enough demographically and, of course, when they agree to speak with one voice!

The exercise we take on here relies mainly on the United Nations' most recent projections made available in May $201 \mathrm{I}$ and called the 2010 Revision. This is the United Nation's 22th projection exercise since the creation of the UN's Commission on Population and Development (CPD) in 1946. Carried out by United Nations experts, this complex periodic exercise serves as a major reference for anyone interested in world demographic trends. Yet it seems that the United Nations' last projections are particular in that they are based on a new approach that outlines a demographic future for the planet, a demographic future quite different from what was put forth in the past. Issued from the UN's most recent prospective exercise, the new overview for future distribution of the world's population seems more consistent with the findings of other researchers and institutions in the last few years (Guengant, 2002; Singer, 2002; Marcoux, 2003, Mathews, 1994). Since demographers rarely reach a consensus, this new data from the United Nations is all the more interesting!

\section{The United Nation's new projections: from the $18^{\text {th }}$ to the $22^{\text {nd }}$ exercise}

An exercise in population projections leads us to hypothesize about the three parameters that determine population growth: natality, mortality and migration. Up until the end of the 20th Century, the United Nation's projections were based on three assumptionsone for each parameter. These assumptions were greatly criticized; particularly the notion of balance that was central in the projections exercises carried out in New York and was applied to each parameter. On the one hand, experts at the United Nations presumed that fertility transitions would converge on a planetary scale towards the famous 2.1 children per woman (a birth rate that guarantees generation replacement in a low-mortality context). On the other hand, these experts 
foresaw a continuous increase in life expectancy at birth for all developing countries. Finally, in terms of migration, it was presumed that we would witness a convergence of all countries towards zero net migration.

Published a decade ago, the "2002 revision" of the projections was representing a major change in direction in the UN demographic forecast approach (Guengant, 2002). In addition to taking into account both the expected effects of the HIV-AIDS pandemic on mortality rates in numerous countries and the complexity of international migration models, the new projections differ with respect to natality: a convergence towards a generation replacement threshold is no longer the proposition that stands out. In fact, the recent studies show that fertility in several developing countries has declined much less quickly than previous forecasts had predicted (Chamie, 20 I I; Bongaarts, 2002; Singer, 2002). However, the anticipated upswing in natality in most developed countries has not taken place since the fertility levels of these countries are often below the generation replacement threshold. Correspondingly, the demographic growth of certain developing countries should be much higher than that predicted by previous projection exercises. Inversely, the new forecasting approach leads us to predict a considerable deceleration in the demographic growth of developed countries. For some regions and countries, this decrease will take place even more quickly because of the demographic ageing that accompanies this phenomenon. Therefore, these new trends undoubtedly imply a major reconfiguration of demographic weight in countries around the world.

\section{Who is part of the Francophonie?}

Though it may seem trivial, this question is not an easy one to answer. There are, in fact, many ways to define the Francophone population according to retained definitions so as to compare with the concept of the Francophonie. In the framework of this study, we will retain two approaches each of which will lead us to propose two future scenarios.

The dictionary definition of Francophonie is as follows:

Group of francophone countries; community formed by countries that use the French language (France, Belgium, Switzerland, Canada, Louisiana, Africa, Madagascar, Lebanon, West Indies, etc.). The Situation of the Francophonie in the World; Francophonie Summit. French Language Movement.

According to this definition, a Francophone is he or she who belongs to one of the so-called Francophone countries in this group. This is similar to the definition retained from our scenario $A \mathbf{A}$ : the Francophone population is one that belongs to countries with full member status in the Organisation internationale de la Francophonie (OIF) in 2010 and where French is the official language. We define these 29 countries as the group of countries of the official Francophonie; in other words, these countries are members of the OIF and have kept French as their official language.

But in fact, the list of members of the OIF also includes a certain number of countries where French is not one of 
the official languages. As a young international Francophone organization, the OIF is largely shaped by the vestiges of the French colonial undertaking of the 19 th and 20th centuries. Following decolonization and independence from French jurisdiction, most ex-colonies have chosen to maintain a connection with France, particularly by actively participating within the authority of the Francophonie. As an international political institution, the Francophonie represents the population of all these countries, regardless of whether or not they have a significant proportion of French speakers. According to scenario $\mathbf{A 2}$, we say that the population identified belongs to active Francophonie countries. These include the entire population of the 29 OIF member countries where French is one of the official languages (this corresponds to the population identified in scenario Al), plus 24 other countries with full membership to the Organisation internationale de la Francophonie in 2010 and where French is not one of the official languages. We therefore include, for example, Northern African countries such as Morocco and Tunisia, Lebanon (a country which contributes significantly to international Francophone migration), and also several Asian countries such as Laos and Vietnam, whose relatively recent history has helped maintain a connection with the political institutions of the Francophonie.

On the basis of these first two scenarios, we could be criticized for defining the Francophonie without taking Francophones into account-quite a paradox! We respond to this criticism by using an approach for our last two scenarios that relies on an estimate of the Francophone population in each country. In fact, we used an indicator based on the estimated number of Francophones in 2010 in more than fifty countries throughout the world. This national indicator was obtained through a wide study using census and other demographic surveys and mostly based on people capability to write and read French (OIF, 2010; Marcoux and Konaté, 2008). It is thus no longer a question of defining the Francophone population by the political and juridical connections that countries maintain with Francophone institutions, but rather of considering the prevalence of French in each of the countries where Francophones are found, though they may make up just a small minority. This is even more similar to the dictionary definition of the word "Francophone":

Person whose mother tongue is French, who mainly uses this language in situations of communication. A Francophone from Belgium or Switzerland. Person who belongs to the Francophone community. Francophones of Montréal or Haiti.

A list of countries and the 2010 estimates of the Francophone proportions of each of these countries can be found in OIF (2010). Scenario B I, Maintaining OIF 2010 Levels, determines the Francophone numbers for the next 50 years according to the proportions obtained in 2010.

This hypothesis of maintaining Francophone proportions in the future may seem quite realistic for Northern Francophone countries and for other nonFrancophone countries (Amrani, 2004; Marcoux, 2010. However, it is another story for some Southern countries, par- 
ticularly in sub-Saharan Africa where French is an official language that is mainly used in the public arena (radio, television, newspapers, public functions, etc.) and, even more important, in the education system.

In these countries, primary, secondary and university schooling takes place almost exclusively in French, although it is true that their education and literacy levels are particularly low. For example, we estimated in 2002 that in Mali less than a third of eligible children attended primary school (Marcoux et al. 2002). Faced with the enormous challenges of development, again, particularly in Africa, and the important role of education, most international workers gathered in Dakar with UNICEF and UNESCO have launched an action program that sets the goal of education for all by the year 2015. Considering the low levels of education in many of the Francophonie's African countries and the extent to which actions taken to raise education levels in the goal of reaching global literacy by 2015 prove to be conclusive, we can expect a substantial increase in proportions of Francophones in these countries in the next decades'.

If all observers agree that there is a lot to do to reach global literacy in Africa, we must recognized the important investment in Education since the 1980 increase considerably the level of French writers and readers in some African countries (Bougma et al. 2010; Marcoux, 2010). This is the conclusions of the recent studies produced at the
Observatoire démographique et statistique de l'espace francophone (ODSEF) for Burkina Faso (Bougma, 2010), Mali (Konaté et al. 2010) and Senegal (Niang Camara, 2010).

Scenario B2, Education of the Francophone Sub-Saharian Africa (SSA), is based on this reading of the future by assuming that the proportion of Francophones in certain countries will continue to increase in the coming decades thanks to a major increase in primary and secondary education in Africa.

For the goals of the present study, we arbitrarily fixed the proportions of French speakers at $85 \%$ for 2060 in Africa's 20 sub-Saharan countries where French is one of the official languages and is used in schooling. Let us point out that $95 \%$ is the rate that was obtained in the Reunion Islands, Martinique and Guadeloupe in 1998.

\section{Results}

As Michel Têtu (1992) points out, census of the world's so-called Francophone population gives rise to many estimates: at the end of the 1980s, these varied between 100 and 150 million people. Simply adding the populations of countries where French is recognized as an official language or still used by a certain proportion of the population would give an estimate of about 380 million people. For Michel Têtu however, this last estimate is not trustworthy "because, unlike South American countries, for example, where a large majority speaks the same

I. Improvement in enrollment rates was brought up in the study by OIF (2010) to explain the observed increase in French speakers in sub-Saharan Africa since the end of the 1980s. Inversely, in countries where there was a deschooling process, we witnessed a decrease in the proportion of Francophones. 
language, the proportion of French speakers in so-called Francophone countries is extremely variable" (Têtu, 1992:208). Jean-Marc Léger (1987) says that the forty or so countries that made up the Francophonie in the 1980s represented $4 \%$ of the world's population (or a little more than 200 million inhabitants), whereas there were about 70 million French speakers in Northern Francophone countries and 30 to 35 million in Southern Francophone countries, essentially on the African continent.

We can differentiate between two distinct approaches for evaluating the demographic weight of the Francophonie. The first is based on what former Secretary General for the Agence de la Francophonie, Jean-Louis Roy, calls the "espace francophone", which regroups the entire political Francophonie: thus, we estimate the population of Francophone countries, to which we add the Francophiles or Francophones outside these countries. In the 1990s, this "espace francophone" regrouped half a billion people (Roy, 1995: 84). The two series $A$ scenarios are faithful to this approach.

The second approach estimates the number of French speakers, or all individuals who use the French language and who master it fully or partially. Jean-Louis Roy estimates that $40 \%$ of French language users (around $180 \mathrm{mil}-$ lion people) could be found in what he calls "l'espace francophone" (Jean-Louis Roy quoted by Le Scouarnec, 1995:22). The two series B scenarios are further based on this approach by referring to the Francophone count carried out in 2010 in the last report of the Organisation international de la Francophonie (OIF,2010)

Table I shows the numbers obtained according to each of the four scenarios. We have thus applied the parameters retained from each scenario to the numbers provided by the United Nation's most recent projections.

Table I Population of the Francophonie using 4 different definitions. Estimation for 1960 and 2010 and Projections for 2060

\begin{tabular}{lcrr}
\hline & 1960 & 2010 & \multicolumn{1}{c}{2060} \\
\hline $\begin{array}{l}\text { Countries approach } \\
\text { Scenario AI : Official Francophonie }\end{array}$ & 148522 & 379954 & 853264 \\
Scenario A2 : Active Francophonie & 289448 & 701581 & 1280825 \\
\hline $\begin{array}{l}\text { French speakers approach } \\
\text { Scenario BI : Maintaining OIF 20 I0 levels }\end{array}$ & & 218264 & 368304 \\
Scenario B2 : Education of Francophone in SSA & & 218264 & 767230 \\
\hline World Population & 3038414 & 6895889 & 9615189
\end{tabular}

Ten years after the turn of the Millennium, we estimate at about 380 million the number people living in the countries where French is official language, and at more than half 700 million those living in countries that participate actively in the institutions of the Franco- phonie. This corresponds with JeanLouis Roy's "espace francophone" that more than doubled its population between 1960 and 2010, and should experience another similar growth over the next 50 years. In this way, countries of the official Francophonie will reach a 
population of 850 million inhabitants while the Francophone space, in its broadest sense (Scenario A2), should exceed a billion inhabitants.

Looking now at the number of French speakers, we estimate close to 220 million for 2010, a number perfectly consistent with the estimates of Roy (1995) and the Haut Conseil de la Francophonie $(1998)^{2}$. This group will also experience major growth, reaching close to 370 million people in 2060 according to the scenario that states that the prevalence of French will plateau in all countries at the level reached in 2010. However, this Francophone population could reach nearly 770 million if French makes rather major headway in African Francophone countries. Should this be the case, the French speaking population would almost quadruple within 50 years.

Of course, we are aware that the components of population growth are different from country to country. As we have already pointed out, Northern countries are well on their way to having aging populations, which, when combined with the drop in fertility, leads to a considerable deceleration in demographic growth and even, in certain cases, to demographic decline. Even though decreased fertility seems to be spreading to most Southern countries, this trend in many African countries is much slower than predicted, thus ensuring that growth potential in these countries will remain high for many years to come. Considering the geographic configuration of the Francophonie's countries and the resulting distribution of Francophones, it could be interesting to look at the current patterns and attempt to outline them for the future.

Table 2 shows the geographic distribution of the Francophonie or of Francophones by continent according to each of the four scenarios. The first observation is that in all scenarios there will be a considerable increase in Africa's demographic weight within the Francophonie, while that of Europe will decrease proportionally. The approach in terms of the Francophone space (scenarios $\mathrm{Al}$ and $\mathrm{A} 2$ ) leads to a doubling of Africa's relative weight in the Francophonie. In a parallel manner, while in 1960 we counted as many individuals belonging to countries of the Francophonie in Europe as in Africa, in 2060, we should count 6 to 7 Francophones in Africa for every individual in the European Francophone space.

Because scenario A2, which defines the active Francophonie as a political space, considers demographic trends in certain largely populated countries (Cambodia, Laos and Vietnam), it is the only one that gives Asia a significant role. However, it is unlikely that this subset will be able to maintain a significant role within the Francophonie's political whole since the already weak proportion of Francophones in these Asian countries should continue to decrease.

Finally, using the speaker-based approach, Africa contained $50 \%$ of all the world's Francophones in 2010 (scenarios BI and B2). In 2060, if the prevalence of French is maintained at the 2010 level, two thirds of Francophones will be on the African continent. The

2. Estimates for 1960 are only possible for the two A scenarios seeing that we have no exact or trustworthy information on world French speakers before 1997. 
scenario that considers that users of the French language in the South are likely to increase would lead us to estimate that, by 2050 , nearly $83,4 \%$ of the world's Francophones will live in Africa. This translates to more than half a billion Francophones on this continent alone.

Table 2 Geographic distribution of population of the Francophonie by continent using 4 different definitions. Estimation for 1960 and 2010 and Projections for 2060.

\section{Scenario Al}

\section{Official Francophonie}

\section{Continents}

Africa

Americas

Asia

Europe

Oceania

Francophone Population Scenario AI

World Population

Scenario A2

Active Francophonie

Continents

Africa

Americas

Asia

Europe

Oceania

Francophone Population Scenario A2

World Population

Scenario B I

French speakers: maintaining to 2010 level

Continents

Africa

Americas

Asia

Europe

Oceania

Francophone Population Scenario BI

World Population

$\begin{array}{ccc}1960 & 2010 & 2060 \\ 44,08 & 66,47 & 81,69 \\ 15,10 & 11,89 & 7,18 \\ 0 & 0 & 0 \\ 40,72 & 21,50 & 11,03 \\ 0,10 & 0,13 & 0,11 \\ 148522 & 379954 & 853264 \\ 3038414 & 6895889 & 9615189\end{array}$

$\begin{array}{ccc}1960 & 2010 & 2060 \\ 40,97 & 58,17 & 73,87 \\ 7,78 & 6,46 & 4,80 \\ 16,27 & 16,62 & 10,70 \\ 34,93 & 18,67 & 10,55 \\ 0,05 & 0,07 & 0,07 \\ 289448 & 701581 & 1280825 \\ 3038414 & 6895889 & 9615189\end{array}$

1960

$2010 \quad 2060$

$50,17 \quad 65,50$

$8,14 \quad 6,56$

$I, 81 \quad 1,35$

$39,60 \quad 26,35$

$0,27 \quad 0,24$

$218264 \quad 368304$

$6895889 \quad 9615189$

\section{Scenario B2}

French speakers: investing in education of Francophone SSA

\section{Continents}

Africa

Americas

Asia

Europe

Oceania

Francophone Population Scenario B2

World Population
1960

2010

50,17

2060

8,14

I,8I $\quad 0,65$

$39,60 \quad 12,65$

$0,27 \quad 0,11$

$218264 \quad 767230$

$6895889 \quad 9615189$ 


\section{Conclusion}

The demographic projection exercise on which we have based our work must of course be examined just like any other perspective's exercise. It is an attempt to outline what might be the demographic future of the Francophonie, or the Francophone world, taking into account the partial and incomplete information available, and based on certain hypotheses that seemed the most plausible. Of course, there are major limitations to this kind of exercise, which is why (to employ the terms of Louis Henry $(198 \mathrm{I})^{3}$ ) we choose to talk about a perspectives exercise rather than a forecasting exercise.

Once aware of these limits, we can affirm that the exercise was successful and has led to the following conclusions:

- The "espace francophone", defined as countries that use French as an official language, can be estimated at 370 million people in 2010 and should surpass 850 million people in 2060. The demographic future of the Francophonie will be played out more and more in Southern countries, particularly in Africa, and therefore in increasingly multilingual national contexts.

- Estimated to reach 220 million people in 2010, the number of French speakers may reach 765 million people in the next fifty years if energetic measures are put in place to promote education for all in Southern countries where schooling already takes place in French. The Francophones that made up less than $3 \%$ of the world population in 2000 could see their demographic weight increase to more than $8 \%$ of the world's population by the middle of the 2 I st century.

On the whole, demographic trends predicted by the United Nations and much of the scientific community of demographers lead to a major reconfiguration of the weight of Nations on an international scale. The Francophone world is in no way spared in this reconfiguration.

- Regardless of which scenario plays itself out, Africa will see its demographic weight increase considerably: whereas Africa was home to half of all the world's Francophones in 2010 , we can expect that close to $84 \%$ of French speakers will be found here in 2060, or more than half a billion of the 760 million Francophones in the world.

Of course, if the demographic future of the Francophonie is to take place in Africa, it will depend on two major conditions.

- That strong and efficient actions in the field of education will enable to substantially raise education levels in Africa's Francophone countries;

- That Africa's Francophone countries and their populations will consider that this significant rise in education levels-necessary for social and economic development-can and must take place

3. "By demographic projection we mean calculation results as a whole, illustrating the future evolution of a population according to this hypothesis or that hypothesis, which are not necessarily plausible. When we choose a less likely hypothesis, following the analysis of a concrete situation, we gladly speak of demographic perspectives. These perspectives cannot take on the meaning of population forecast unless the hypotheses on which they are founded seem to be very probable”.(Henry, 198 I page 102-103) 
within the framework of teaching and training programs carried out in French.

Given the multilingualism practiced in most African countries (including Francophone countries), it will be necessary to identify the place that the French language will have and the role it will play in relationship not only to the other languages spoken in these countries, but also to the languages making headway on a global scale, particularly English, Arabic, Portuguese and Spanish. Considering the disproportionate gap between the financial means of Northern and Southern countries, it is obvious that the demographic future of the Francophonie will depend largely on the acts of solidarity and efforts that Northern Francophonie member countries will be willing to grant to the Francophone countries of Africa. Participants in the Francophonie will also have a major role to play in order to spark and/or maintain the interest in developing French in many of Africa's sectors, particularly in the media (written, radio, audiovisual and electronic), in the arts (cinema, literature, etc.) and in the areas of education and scientific research.

\section{References}

AMRANI, Yousra, 2004. "L'agonie de la langue française au Maroc ", La Gazette du Maroc, no 354, 9 février 2004 (www.lagazettedumaroc.com)

BONGAARTS, John, 2002. «The End of the Fertility Transition in the Developed World ", Population and Development Review, vol 28, no 3, pp. $419-443$

BOUGMA, Moussa, 2010. " Dynamique des langues locales et de la langue française au Burkina Faso: un éclairage à travers les recensements généraux de la population (1985, 1996 et 2006)", Rapport de recherche, Observatoire démographique et statistique de l'espace francophone, Université Laval, $61 \mathrm{p}$.

BOUGMA, Moussa, Mamadou Kani KONATÉ et Richard MARCOUX, 2010 . " Les populations francophones au Burkina et au Mali depuis le milieu des années 1980 ", La langue française dans le monde. 2010, sous la direction d'Alexandre Wolff, Paris, Éditions Nathan, pp. 50-52

CHAMIE, Joseph, 20II. «Africa's Demographic Multiplication», The Globalist, June I3th 20II.

GUENGANT, Jean-Pierre, 2002. " 'Révolution' dans le champ des projections démographiques », La lettre du CICRED (Supplément), no 6, pages $9-12$

HAUT CONSEIL DE LA FRANCOPHONIE, 1998. État de la francophonie dans le monde. Paris, La Documentation Française. 592 pages

HENRY, Louis, 198I. Dictionnaire démographique multilingue, (deuxième édition), Liège,. Ordina Éditions, 179 pages

KONATÉ, Mamadou Kani, Idrissa DIABATÉ et Amadou ASSIMA (2010), " Dynamique des langues locales et de la langue française au Mali : un éclairage à travers les recensements généraux de la population (1987 et 1998), Rapport de recherche, Observatoire démographique et statistique de l'espace francophone, Université Laval, 46p. 
LÉGER, Jean-Marc, 1987. La Francophonie : grand dessin, grande ambiguïté, Montréal, Hurtubise $\mathrm{HMH}, 24 \mathrm{I}$ pages

LE SCOUARNEC, François-Pierre, 1997. La Francophonie, Montréal, Boréal, 126 pages

MATHEWS, Georges, 1994. "L'avenir de la population mondiale. Quand les perspectives officielles se trompent lourdement ", Futurible, no 190, pp. 45-65

MARCOUX, Richard (2010), " Les populations francophones : passé, présent et perspectives ", La langue française dans le monde. 2010, sous la direction d'Alexandre Wolff, Paris, Éditions Nathan, pp. 45-50

MARCOUX, Richard et Mamadou Kani KONATÉ, (2008), "Les sources de données démo-linguistiques en Afrique francophone "Séminaire international sur la méthodologie d'observation de la langue française dans le monde, AUF-OIF, Paris (juin 2008), pp. 35I-367

MARCOUX, Richard avec la collaboration de Mathieu GAGNÉ (2003), «La Francophonie de demain : essai de mesure de la population appartenant à la Francophonie d'ici 2050», Cahiers québécois de démographie, vol. 32, no 2, pp. $273-$ 294

MARCOUX, Richard, Mohamadou GUÉYE et Mamadou K. KONATÉ, 2002. «Environnement familial, itinéraires scolaires et travail des enfants au Mali. ", Enfants d'aujourd'hui. Diversité des contextes, pluralité des parcours, colloque organisé par l'Association internationale des démographes de langue français (AIDELF), Dakar 913 décembre 2002

NIANG CAMARA, Fatou Bintou (2010), "Dynamique des langues locales et de la langue française au Sénégal en 1988 et 2002 ", Rapport de recherche, Observatoire démographique et statistique de l'espace francophone, Université Laval, 4 I p.

OIF (ORGANISATION INTERNATIONALE DE LA FRANCOPHONIE), 2003. La Francophonie dans le monde, 20022003. Paris, Larousse, 320 pages.

OIF (ORGANISATION INTERNATIONALE DE LA FRANCOPHONIE), 20I0. La langue française dans le monde. 2010. Paris, Nathan, 384 pages.

ROY, Jean-Louis, 1995. Mondialisation, développement et culture : la médiation francophone. Montréal, Hurtubise $\mathrm{HMH}, \mathrm{I} 55$ pages

SINGER, Max, 2002. "Uncertainties in the Composition of World Population in the Twenty-First Century", Population and Development Review, vol 28, no 3, Pp. 539-548

TÊTU, Michel, 1992. La Francophonie : histoire, problématique et perspectives, Montréal, Guérin Universitaire, 426 pages.

United Nations, Population Division, 201I. World Population Prospects. The 2010 Revision Population Database. (http://esa.un.org/unpp/) 